\title{
In-Service Science Teachers' Technological Pedagogical Content Knowledge Confidences and Views about Technology-Rich Environments
}

Betül Timur ${ }^{1}$ and Mehmet Fatíh TaşaR ${ }^{{ }^{2}}$

$\approx$ Today's computers and related technologies have an important role in enabling visualisations of the workings of various scientific concepts, natural phenomena and mechanisms by creating technology-rich environments (TRE). TRE offer opportunities to science teachers in cases of natural phenomena that might be difficult or impossible to view, dangerous to conduct experiments about, impractical or too expensive to bring into the classroom, or too messy or time consuming to prepare in a school laboratory. However, science teaching cannot and should not be undertaken entirely by TRE. Science teachers need to know how to integrate technology into science classrooms. Measuring science teachers' confidence in technological pedagogical content knowledge (TPCK) and identifying their views about using TRE in science instruction is an important issue. The present study aims to address challenges faced by in-service science teachers when creating TRE and gives suggestions for successful technology integration into science teaching. The data were gathered through a TPCK confidence survey and subsequent interviews. The results show that in-service science teachers have a low level of confidence in using technology during science teaching. The teachers surveyed stressed their need for professional development activities regarding the effective and meaningful use of TRE in science teaching.

Keywords: In-service teachers, Mixed methods research, Teacher confidence, Technological pedagogical content knowledge, Technology-rich environments

1 Çanakkale Onsekiz Mart Üniversitesi, Eğitim Fakültesi, C Blok 106, 17100, Çanakkale, Turkey bapaydin@comu.edu.tr

2 *Corresponding author. Gazi Üniversitesi, Gazi Eğitim Fakültesi, K Blok 21006500 , Teknikokullar, Ankara, Turkey

mftasar@gazi.edu.tr 


\section{Samozaupanje učiteljev naravoslovja v njihovo tehnološko-pedagoško znanje in njihova stališča do tehnološko bogatih okolij}

Betül Timur in Mehmet Fatih Taşar*

$\approx$ Danes imajo računalniki in z njimi povezane informacijsko-komunikacijske tehnologije (IKT) v t. i. tehnološko bogatih okoljih (TBO) pomembno vlogo pri vizualizaciji različnih naravoslovnih pojmov in pojavov. TBO učiteljem naravoslovja nudijo možnosti prikaza naravoslovnih pojavov, ki jih je težko ali nemogoče videti, nevarno izvajati, so nepraktični ali predragi, da bi se jih prineslo v učilnico, njihovo izvajanje povzroči preveč nereda ali pa so časovno preveč neekonomični, da bi se jih dalo prikazati v šolskem laboratoriju. Kljub temu pa se pouk naravoslovja ne more in tudi ne sme v celoti izvajati s pomočjo TBO. Učitelji naravoslovja morajo poznati smernice učinkovite integracije IKT v pouk. Pri tem je pomembno, da se določi samozaupanje učiteljev naravoslovja $\mathrm{v}$ svoje tehnološko-pedagoško znanje in ugotovi njihova stališča do uporabe TBO pri pouku naravoslovja. Cilji te študije so ugotoviti, s katerimi izzivi se srečujejo učitelji naravoslovja med ustvarjanjem TBO, in podati predloge za uspešno integracijo IKT v pouk naravoslovja. Podatki so bili zbrani z uporabo vprašalnika o samozaupanju učiteljev v svoje tehnološko-pedagoško znanje in intervjuji. Izsledki kažejo, da imajo učitelji naravoslovja nizko samozaupanje v znanje o uporabi IKT pri pouku naravoslovja in da poudarjajo pomen profesionalnega razvoja na področju TBO, da bi IKT lahko učinkovito in smiselno vključevali v pouk.

Ključne besede: tehnološko bogato okolje, tehnološko-pedagoško znanje, učitelji, samozaupanje učiteljev 


\section{Theoretical background}

Towards the end of the last century, we witnessed the beginning of the widespread use of computer technologies in science classrooms, and practically everywhere else, as personal computer hardware with ever higher capacities became affordable to larger populations and applications with enhanced visual characteristics were created with less effort, not only by computer experts but also by science educators. Although not sufficient for all teachers, several initiatives and efforts emerged in order to help science teachers to better understand the associated teaching methodologies and the benefits of technology-rich environments (TRE) in science.

In the coming years, computing is expected to become increasingly effective and indispensible in the processes of science, as is expressed in the "Towards 2020 Science" report: "Scientists will need to be completely computationally and mathematically literate, and by 2020 , it will simply not be possible to do science without such literacy. This therefore has important implications for education policy right now" (The Science Group, 2006, p. 8). By reviewing existing empirical studies, however, a recent paper (Hew \& Brush, 2007) identified 123 barriers faced by teachers. The authors classified these barriers into six main categories: (a) resources, (b) knowledge and skills, (c) institutions, (d) attitudes and beliefs, (e) assessment, and (f) subject culture.

In an OECD report entitled " $21^{\text {st }}$ Century Learning Environments", the role of schools is specified as follows: "Today, ICT skills - from completing a simple search on the Internet and writing an essay in Word, to cutting a video and designing a Web page - are a prerequisite for entry into the workforce. Schools have an important role to play in providing students with the necessary skills to become tomorrow's knowledge workers" (OECD, 2006, p. 20). In-service science teachers have an important role to play creating successful TRE in science teaching.

\section{Science teachers' technological pedagogical content knowledge}

Technological pedagogical content knowledge (now known as TPCK or TPACK) has become a commonly referenced conceptual framework of teacher knowledge for technology integration within teacher education. TPCK is described as a complex interaction of content, pedagogy and technology, as well as discussion on the successful integration of technology into instruction (Koehler \& Mishra, 2008). In recent years, researchers have described TPCK within the framework Schulman's $(1986,1987)$ description of pedagogical content knowledge (PCK). 
According to Schulman (1986, p. 9), PCK "goes beyond the knowledge of subject matter per se to the dimension of subject matter knowledge for teaching", thus being the connection and relationship between pedagogy and content knowledge. Researchers have conceptualised PCK in the domain of teaching with technology using different schemes: "Margerum-Lays and Marx (2003) referred to PCK of educational technology, Slough and Connell (2006) used the term technological content knowledge, and Mishra and Koehler (2006) suggested the term technological pedagogical content knowledge (TPCK) - a comprehensive term that has prevailed in the literature" (as referred to and cited in Angeli \& Valanides, 2009, p. 155). TPCK can be described as how teachers understand educational technologies and how PCK interacts with technology to produce effective teaching with technology. Table 1 shows the PCK conceptualisations of ten scholars.

Mishra and Koehler's (2006) definition of TPCK is that "[it is] the basis of effective teaching with technology, requiring an understanding of the representation of concepts using technologies; pedagogical techniques that use technologies in constructive ways to teach content; knowledge of what makes concepts difficult or easy to learn and how technology can help redress some of the problems that students face; knowledge of students' prior knowledge and theories of epistemology; and knowledge of how technologies can be used to build on existing knowledge to develop new epistemologies or strengthen old ones." On the other hand, Angeli and Valanides (2009) assert that "content, pedagogy, learners, and technology are contributing knowledge bases to TPCK, but knowledge and growth in each contributing knowledge base alone, without any specific instruction targeting exclusively TPCK as a unique body of knowledge, does not imply automatic growth in TPCK". The authors go on to relate ICT to TPCK, defining TPCK in the following manner: "the ways knowledge about tools and their pedagogical affordances, pedagogy, content, learners, and context are synthesized into an understanding of how particular topics that are difficult to be understood by learners, or difficult to be represented by teachers, can be transformed and taught more effectively with ICT, in ways that signify the added value of technology." 
Table 1: Components of Pedagogical Content Knowledge from different conceptualisations (Van Driel, Verloop \& De Vos, 1998; Park \& Oliver, 2008).

\begin{tabular}{|c|c|c|c|c|c|c|c|c|c|}
\hline \multirow[b]{2}{*}{ Scholars } & \multicolumn{9}{|c|}{ Knowledge of } \\
\hline & 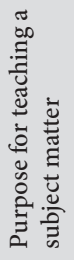 & 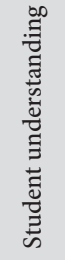 & $\frac{\Xi}{\Xi}$ & 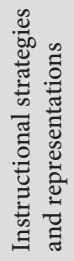 & 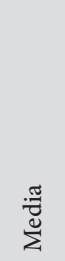 & 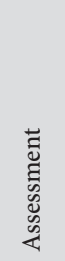 & 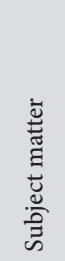 & 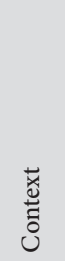 & 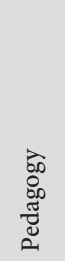 \\
\hline Shulman (1987) & d & PCK & $\mathrm{d}$ & PCK & - & - & $\mathrm{d}$ & d & $\mathrm{d}$ \\
\hline Tamir (1988) & - & PCK & PCK & PCK & - & PCK & $\mathrm{d}$ & - & $\mathrm{d}$ \\
\hline Grossman (1990) & PCK & PCK & PCK & PCK & - & - & $\mathrm{d}$ & - & - \\
\hline Marks (1990) & - & PCK & - & PCK & PCK & - & PCK & - & - \\
\hline Smith and Neale (1989) & PCK & PCK & - & PCK & - & - & $\mathrm{d}$ & - & - \\
\hline Geddis et al. (1993) & - & PCK & PCK & PCK & - & - & $\mathrm{u}$ & - & - \\
\hline Fermandez et a. (1995) & PCK & PCK & $\mathrm{u}$ & PCK & - & - & PCK & PCK & - \\
\hline Magnusson et al. (1999) & $\mathrm{PCK}^{*}$ & PCK & PCK & PCK & - & PCK & - & - & - \\
\hline Hasweh (2005) & PCK & PCK & PCK & PCK & - & PCK & PCK & PCK & PCK \\
\hline Loughran et al. (2006) & PCK & PCK & - & PCK & - & - & PCK & PCK & PCK \\
\hline
\end{tabular}

PCK: Author(s) include this subcategory as a component of PCK.

d: Author(s) place this subcategory outside PCK as a distinct knowledge base for teaching.

"Researchers in science education refer to this component as one's "orientation toward teaching".

\section{The aim of the study and research questions}

The present study aims to measure in-service science teachers' TPCK confidences and identify their views about using technology-rich environments (TRE) in science. We also aim to address challenges faced by in-service science teachers in creating TRE, and to give suggestions for successful technology integration in science teaching.

The study focuses on the following research questions:

1. What are in-service science teachers' perceived confidence levels in four TPCK constructs (i.e., technological knowledge, technological pedagogical knowledge, technological content knowledge, technological pedagogical content knowledge)?

2. What are in-service science teachers' views, needs and classroom practices regarding TRE? 


\section{Method}

\section{Participants}

A non-random purposeful sample was used to gather data from in-service science teachers. Ninety-five public school science teachers participated in the survey on a voluntary basis. Sample characteristics are summarised in Table 2.

Table 2: Participants' characteristics.

\begin{tabular}{lrr}
\hline Participants' characteristics & F & $\%$ \\
\hline Gender & & \\
Female & 44 & 46.3 \\
Male & 51 & 53.7 \\
\hline Teaching hours per week & & \\
10-14 & 10 & 10.5 \\
15-19 & 35 & 36.8 \\
20-24 & 38 & 40.0 \\
25-19 & 10 & 10.5 \\
29-34 & 2 & 2.1 \\
\hline Number of students in teacher's classroom & & \\
Less than 20 & 10 & 10.5 \\
21-30 & 60 & 63.2 \\
31-40 & 21 & 22.1 \\
41-50 & 4 & 4.2 \\
\hline Teacher's professional experience & & \\
1-5 years & 17 & 17.9 \\
6-10 years & 35 & 36.8 \\
11-15 years & 23 & 24.2 \\
16-20 years & 13 & 13.7 \\
More than 21 years & 7 & 7.4 \\
\hline & &
\end{tabular}

\section{Instruments}

The TPCK confidence-science instrument has been adapted to Turkish from Graham, Burgoyne, Cantrell, Smith, Clair and Harris (2009).

The original survey instrument was created by Graham et al. and consists of 31 Likert-type items. Respondents were asked: "How confident are you in your current ability to complete each of the following tasks?" Responses were given in the form of 6-point Likert-type questions: $1=$ not confident at all, 2=slightly confident, 3=somewhat confident, 4=fairly confident, 5=quite 
confident, $6=$ completely confident (the scale for TCK items also had o=I don't know about this kind of technology). The areas of TPCK, TPK, TCK and TK were created by combining the domains of content, pedagogy and technology. The original instrument contains eight items related to TPCK, seven items related to TPK, five items related to TCK, and 11 items related to TK in order to measure in-service science teachers' TPCK confidence.

Survey adaptation steps suggested by Brislin (1970), White and Elander (1992) were used in the present study (as cited in Hall, Wilson, \& Frankenfield, 2003). The steps were: “1) use short and simple language; 2) secure competent translators who are familiar with the issue; 3) have a refinement group for both translations", while the back-translation method was considered to be the preferred method of obtaining a culturally equivalent instrument (Erkut, Alarcon, Garcia Coll, Troop, \& Vazguez Garcia, 1999). After translating the instrument into Turkish, a back translation into English was made for checking purposes. First, three native Turkish speakers made their translations independently. Two of the translators hold $\mathrm{PhD}$ degrees in science education and the other is a lecturer at the Department of Computer and Instructional Technologies Teaching. The authors compared these three translations and formed a Turkish version of the instrument for back translation. Second, three back translations into English were made by three independent Turkish individuals with $\mathrm{PhD}$ degrees. Finally, the authors compared the three back translations and created the final version of the instrument for the main study.

A revised version of the scale was administered to 393 science and technology teachers to determine its validity and reliability. A factor analysis method yielded the construct validity of the scale. Confirmatory factor analysis (CFA) was used to ensure compliance with Turkish culture. The instrument consisted of 31 items and four dimensions: technological pedagogical content knowledge (TPCK), technological pedagogical knowledge (TPK), technological content knowledge (TCK) and technological knowledge (TK). Reliability analysis of the instrument revealed that the Cronbach-Alpha coefficient was very high (.92) for the whole instrument. The reliability coefficients of the four sub-dimensions were also very high, at $.89, .87, .89$ and .86 respectively for the TPCK, TPK, TCK, and TK sub-dimensions (Timur \& Taşar, 2011). These results showed that TPCK confidence can be used in Turkey for measuring the TPCK confidence of in-service teachers. The sample items for each dimension are given in Table 3 below. 
Table 3: Sample items of the TPCK confidence survey for each dimension.

\begin{tabular}{|c|c|}
\hline Sub-factor & Sample items \\
\hline TPCK & $\begin{array}{l}\text { - use online animations that effectively demonstrate a specific scientific principle, } \\
\text { - help students use digital technologies to organise and identify patterns in scien- } \\
\text { tific data, } \\
\text { - use digital technologies that facilitate topic-specific science activities in the } \\
\text { classroom, }\end{array}$ \\
\hline TPK & $\begin{array}{l}\text { - } \quad \text { use digital technologies to motivate learners, } \\
\text { _ } \quad \text { use digital technologies to help in assessing student learning, }\end{array}$ \\
\hline TCK & $\begin{array}{l}\text { - use digital technologies that allow scientists to observe things that would otherwi- } \\
\text { se be difficult to observe, } \\
\text { - use digital technologies that allow scientists to speed up or slow down the repre- } \\
\text { sentation of natural events, }\end{array}$ \\
\hline TK & $\begin{array}{l}\text { - create and edit a video clip, } \\
\text { - create a basic presentation using PowerPoint or a similar programme. }\end{array}$ \\
\hline
\end{tabular}

Additionally, face to face semi-structured interviews were conducted with four of the participants. Interviews were conducted with two male and two female science teachers. Four questions were asked in order to probe how they create TRE in their classrooms. The following questions were asked during the interviews: (1) For what purposes do you use computers in teaching science? (2) What are the barriers to TRE in teaching science? (3) How do you currently use computers to support your science teaching? and (4) How do you create TRE in science teaching?

\section{Research design}

Both quantitative and qualitative research methods were used to investigate the level of TPCK confidence. The instrument was emailed to more than 450 in-service teachers. The survey was completed and returned by 101 teachers, but six of the respondents were excluded due to missing data.

The data were analysed using the Statistical Package for the Social Sciences (SPSS), and semi-structured interviews with the teachers were recorded in audio and transcribed verbatim. The aim of the interviews was to collect more detailed data from the participants, and to find out the in-service science teachers' views, needs and classroom practices regarding TRE. Qualitative research must show enough detail for the reader to be able to see the case clearly in order for the researcher's conclusion to make sense (Creswell, 1998). 


\section{Results}

In order to address the question of the perceived confidence level of inservice science teachers' related to the four TPCK constructs, teachers were asked, "How would you rate your confidence in doing the following tasks associated with technology usage?" Thirty-one items in the areas of technological knowledge (TK), technological pedagogical knowledge (TPK), technological content knowledge (TCK), and technological pedagogical content knowledge (TPCK) were asked, and responses were made on a 5-point scale reflecting the level of confidence. Means were calculated for all items, and the average mean for the four sub-factors is shown in Table 5, while Table 4 shows the ranges of confidence levels formed.

Table 4: The confidence intervals for the Likert scale.

\begin{tabular}{ll}
\hline Interval Range & Confidence Level \\
\hline $1.00-1.79$ & not confident at all \\
\hline $1.80-2.59$ & slightly confident \\
\hline $2.60-3.39$ & somewhat confident \\
\hline $3.40-4.19$ & fairly confident \\
\hline $4.20-5.00$ & completely confident \\
\hline
\end{tabular}

Table 5: Summary of descriptive statistics for sub-factors for the question, "How would you rate your confidence in doing the following tasks associated with technology usage?”

\begin{tabular}{lccccccc}
\hline \multirow{2}{*}{ Sub-Factor } & \multicolumn{3}{c}{ Scale } & \multicolumn{3}{c}{ Item } \\
\cline { 2 - 8 } & No. of Items & Min. & Max. & Mean & SD & Mean & SD \\
\hline TPCK & 8 & 8.00 & 40.00 & 25.63 & 7.24 & 3.20 & 0.91 \\
\hline TPK & 7 & 11.00 & 35.00 & 22.24 & 5.30 & 3.18 & 0.76 \\
\hline TCK & 5 & 5.00 & 25.00 & 15.82 & 4.88 & 3.16 & 0.98 \\
\hline TK & 11 & 18.00 & 55.00 & 36.62 & 9.71 & 3.33 & 0.88 \\
\hline
\end{tabular}

According to their responses, the teachers asserted that they feel somewhat confident in all of the four sub-factors. However, they asserted that of the four sub-factors they feel most confident in technological knowledge $\left(\mathrm{TK}_{\text {mean }}=3.33\right)$. They feel somewhat confident in their knowledge of how to use technology and how to teach more effectively with technology, as well as to help 
students meet any specific curriculum content and to use technologies appropriately in their learning. "In other words, merely knowing how to use technology is not the same as knowing how to teach with it" (Mishra \& Koehler, 2006).

The second research question was "What are in-service science teachers' views, needs, and classroom practices regarding TRE?" In order to answer this question, five questions were put to 95 in-service science teachers, and semistructured interviews were conducted with four teachers.

In their responses to the questions about TRE, teachers asserted that computer facilities at their schools are not good enough to create TRE, so they generally give computer-based instruction to the whole class. They also asserted that almost all teachers require professional development regarding how to use computers in science instruction. There is a need to provide technological pedagogical content knowledge confidence to in-service science teachers in order to create optimally functioning technology enhanced classrooms.

Table 6: Descriptive statistics of teachers' views about TRE in science.

\begin{tabular}{|c|c|c|}
\hline Computer facilities & $\mathrm{f}$ & $\%$ \\
\hline \multicolumn{3}{|l|}{ Computer facilities at the school } \\
\hline No computers at school & 6 & 6.3 \\
\hline One computer in each class & 28 & 29.7 \\
\hline Computer lab at school & 41 & 43.2 \\
\hline One computer used for several classes & 20 & 21.1 \\
\hline \multicolumn{3}{|c|}{ Hours per week of computer-based instruction } \\
\hline 1 & 17 & 17.9 \\
\hline 2 & 33 & 34.7 \\
\hline 3 & 17 & 17.9 \\
\hline 4 & 11 & 11.6 \\
\hline More than 4 & 17 & 17.9 \\
\hline \multicolumn{3}{|c|}{ Group size in classes with computer-based instruction } \\
\hline One computer for each student & 5 & 5.3 \\
\hline One computer for two students & 8 & 8.4 \\
\hline Small groups & 11 & 11.6 \\
\hline Whole class & 71 & 74.7 \\
\hline \multicolumn{3}{|l|}{ Computer-based instruction years } \\
\hline 0 & 10 & 10.5 \\
\hline $1-5$ & 72 & 75.7 \\
\hline $6-10$ & 13 & 13.8 \\
\hline \multicolumn{3}{|c|}{$\begin{array}{l}\text { Need for professional development regarding using a computer for instruction } \\
\text { in science }\end{array}$} \\
\hline Yes & 74 & 77.9 \\
\hline No & 21 & 22.1 \\
\hline
\end{tabular}


Teachers asserted that they use computers for showing animations, simulations, videos and films, and for making representations with PowerPoint during instruction. The barriers to TRE were: lack of access to Internet at school; difficulty in locating and executing technology-rich materials, such as animations, simulations and videos, for every subject; the pre-class planning and preparation required to create TRE; and classroom management problems. Teachers tend to group the whole class for TRE and show animations, simulations and videos using a projector. They asserted that they sometimes stop the video or animation and ask the class questions about the subject. One teacher described the current use of computers in his science instruction as follows:

I usually use animations or videos in instruction. It is difficult to find visualisations for every subject in science since most science subjects are abstract. I have to spend time preparing in order to create technologyrich science lessons. However, students in my class are highly motivated when I use visualisations in my science teaching. In the last lesson, I used a cartoon animation of blood cells in my class. The whole class watched the animation together and solved a puzzle after the animation. However, sometimes watching a video or animation in a science lesson cannot be different from watching a movie at the cinema.

Another teacher described her technology-rich class as follows:

I use a projector when I use a computer in my class. I arrange students' seats in the best way for them to see the whiteboard. I start the lesson with brainstorming about the subject then we watch a video or animation. I do not usually have classroom management problems because students are highly motivated when they are watching a video or animation. However, sometimes students find their peers' questions ridiculous or foolish.

\section{Conclusions}

The present study shows that in-service science teachers do not have sufficient TPCK confidence to create TRE in science teaching, and that they need professional development on the use of TRE in science teaching. Teachers need to have confidence to use technology as an enrichment rather than as a replacement in science teaching. Koch (2005, p. 25) emphasises that technology alone cannot help students to learn science. As she explains, a computer can become part of the science learning experience if the child feels a need to 
use it in learning, and such a need can be created, for example, while exploring what causes different weather conditions. In this case, students can easily access weather reports on the Internet. This act makes the computer a useful and meaningful tool in learning. Such use can also be found in many other computer applications (e.g., certain software packages and online resources) that allow students to explore science phenomena in a simulated environment. In a way, access to interactive manipulation of the simulated phenomena forms a science laboratory that allows the child to study and learn at her or his convenience. Successfully integrating technology into science education relies heavily on the development of well-built, coherent professional development programmes that are designed with a clear understanding of how teachers can use technology in their class in the most effective way.

Some recent studies have focused on the barriers effecting technology integration, such as limited access to the Internet, classroom size and lack of teacher knowledge about successful technology integration into instruction (Çakır \& Yıldırım, 2009; Cure \& Özdener, 2008). Other research indicates that PD programmes have a positive impact on teacher development of TPACK (Guzey \& Roehrig, 2009; Graham et al., 2009; Varma, Husic \& Linn, 2008) and can help teachers to successfully integrate technology into their practice (Niess, 2005; Harris, Mishra, \& Koehler, 2009).

There is a need to provide TPCK confidence to in-service science teachers in order to create optimally functioning technology-enhanced classrooms. It is important to devote time and effort to $\mathrm{PD}$ programmes, to exploring the cognitive, transformative and pedagogical aspects of adopting educational technology in teaching, rather than merely presenting the hardware and software to be used (Sturdivant, Dunham, \& Jardine, 2009).

Recent reports of the Turkish Education Association (2009, p. 174) regarding teacher competences assert that both in-service and pre-service teachers need to have technology competences, or so-called technological pedagogical content knowledge. They have to know how to integrate technology into their instruction and create effective technology-rich environments. Recent studies of teacher competences in creating TRE show that primary school teachers fail to use instructional software in their lessons, and that most teachers do not even know whether there is any software available in their fields (Kazu \& Yavuzalp, 2008). On the other hand, instructional software is inadequate at primary and secondary school level, and the existing instructional software is not aligned with the subjects in the primary and secondary school curriculum. Furthermore, although primary science teachers and secondary physics teachers believe that it is effective to use computers in instruction, they 
do not know how to do so and need professional development and support in this area (Uzal, Erdem, \& Ersoy, 2009). In another study, it is stated that primary school teachers have inadequate competences for using computers in instruction (Balkı \& Saban, 2009). In light of these results, in our professional development we will focus on the development of in-service science teachers' technological pedagogical content knowledge, and aim at increasing student achievement in primary school science lessons by utilising interactive computer animations in Force and Motion course subjects.

Successfully integrating technology into science education relies heavily on the development of well-built, coherent professional development programmes that are designed with a clear understanding of how teachers need to use technology in their class in the most effective way. Science teachers need to have the competence of technological pedagogical content knowledge in their particular discipline.

\section{Acknowledgements}

This study was presented at ESERA 2011 as an oral presentation. It was financed by the $7^{\text {th }}$ Framework of European Union Research Projects EC contract GA 234870 S-TEAM (Science Teacher Education Advanced Methods).

\section{References}

Angeli, C., \& Valanides, N. (2009). Epistemological and methodological issues for the conceptualization, development, and assessment of ICT-TPCK: Advances in technological pedagogical content knowledge (TPCK). Computers \& Education, 52(1), 154-168.

Balkı, E., \& Saban, E. (2009). Öğretmenlerin Bilişim Teknolojilerine İlişkin Algıları ve Uygulamalar: Özel Esentepe İlköğretim Okulu (Teachers' Perceptions and Practices of Information Technologies: The Case of the Esentepe Private Elementary School). İlköğretim Online, 8(3), 771-781. Creswell, J. W. (1998). Qualitative Inquiry and Research; Choosing Among Five Traditions. Thousand Oaks, CA: Sage Publications.

Cüre, F., \& Özdener, N. (2008). Öğretmenlerin Bilgi ve İletişim Teknolojileri (BİT) Uygulama Başarıları ve BİT’e Yönelik Tutumları. Hacettepe Üniversitesi Eğitim Fakültesi Dergisi, 34(1), 41-53. Çakır, R., \& Yıldırım, S. (2009). Bilgisayar Öğretmenleri Okullardaki Teknoloji Entegrasyonu Hakkında Ne Düşünürler? Elementary Education Online, 8(3), 952-964.

Erkut, S., Alarcon, O., Garcia Coll, C., Troop, L. R., \& Vazguez Garcia, H. A. (1999). The dual-focus approach to creating bilingual measures. Journal of Cross-Cultural Psychology, 3o(1), 206-218. Graham, C. R., Burgoyne, N., Cantrell, P., Smith, L., St. Clair, L., \& Harris, R. (2009). TPACK Development in Science Teaching: Measuring the TPACK Confidence of In-service Science Teachers. 
TechTrends, 53(5), 70-79.

Guzey, S. S., \& Roehrig, G. H. (2009). Teaching science with technology: Case studies of science teachers' development of technology, pedagogy, and content knowledge. Contemporary Issues in Technology and Teacher Education, 9(1), 25-45.

Hall, E. O., Wilson, M. E., \& Frankenfield, J. A. (2003). Translation and Restandardization of an Instrument: The Early Infant Temperament Questionnaire. Journal of Advanced Nursing, 42(2), 159168.

Harris, J., Mishra, P., \& Koehler, M. (2009). Teachers' Technological Pedagogical Content Knowledge and Learning Activity Types: Curriculum-based Technology Integration Reframed. Journal of Research on Technology in Education, 41(4), 393-416.

Hew, K. F., \& Brush. T. (2007). Integrating technology into K-12 teaching and learning: Current knowledge gaps and recommendations for future research. Education Technology Research Development, 55(3), 223-252.

Kazu,. İ. Y., \& Yavuzalp, N. (2008). Öğretim Yazılımlarının Kullanımına İlişkin Öğretmen Görüşleri (Teachers' Opinions on the Use of Instructional Software). Eğitim ve Bilim, 33(150), 110-126. Koch, J. (2005). Science Stories: Science Methods for Elementary and Middle School Teachers ( $3^{\text {rd }}$ Ed.). Boston: Houghton Mifflin.

Koehler, M., \& Mishra, P. (2008). Introducing TPCK. In AACTE Committee on Innovation and Technology (Eds.), The handbook of technological pedagogical content knowledge for teaching and teacher educators (pp. 3-29). Mahwah, NJ: Lawrence Erlbaum Associates, Publishers.

Mishra, P., \& Koehler, M. J. (2006). Technological pedagogical content knowledge: A framework for integrating technology in teacher knowledge. Teachers College Record, 108(6), 1017-1054.

Niess, M. L. (2005). Preparing teachers to teach science and mathematics with technology:

Developing technology pedagogical content knowledge. Teaching and Teacher Education, 21(5), 509523.

Organization for Economic Co-operation and Development (OECD) (2006). 21st Century Learning Environments. OECD Publishing.

Park, S., \& Oliver, J. S. (2008). Revisiting the conceptualisation of pedagogical content knowledge (PCK): PCK as a conceptual to understand teachers as professionals. Research in Science Education, $38(3), 261-284$.

The Science Group (2006). Towards 2020 Science, Microsoft Corporation, Cambridge,

MA. Retrieved 13.09.09 from http://research.microsoft.com/enus/um/cambridge/projects/

towards2020science/

downloads/t2020s_reporta4.pdf.

Shulman, L. S. (1986). Those who understand: Knowledge growth in teaching. Educational

Researcher, 15(2), 4-14.

Shulman, L. S. (1987). Knowledge and teaching: Foundations of the new reform. Harvard Educational Review, $57(1), 1-22$.

Sturdivant, R. X., Dunham, P., \& Jardine, R. (2009). Preparing Mathematics Teachers for 
Technology-Rich Environments. PRIMUS, 19(2), 161-173.

Timur, B., \& Taşar, M. F. (2011). Teknolojik Pedagojik Alan Bilgisi Öz Güven Ölçeğinin (TPABÖGÖ) Türkçeye Uyarlanması (The Adaptation of the Technological Pedagogical Content Knowledge Confidence Survey to Turkish). Gaziantep Üniversitesi Sosyal Bilimler Dergisi, 1o(2), 839-856. Türk Eğitim Derneği (Turk Education Association) (2009). Öğretmen Yeterlikleri (Teacher Competences). Ankara: Adım Okan Matbaacılık Basım.

Uzal, G., Erdem, A., \& Ersoy, Y. (2009). Bilgisayar Destekli Fen Bilgisi/Fizik Eğitimi: Öğretmenlerin Genel Eğilimleri ve Gereksinimleri (Computer-Based Science/Physics Education: Teachers' General Tendencies and Needs). Milli Eğitim, 38(183), 380-39o.

Varma, K., Husic, F., \& Linn, C. M. (2008). Targeted Support for Using Technology-Enhanced Science Inquiry Modules. Jounal of Science Education Technology, 17(4), 341-356.

Van Driel, J. H., Verloop, N., \& De Vos, W. (1998). Developing science teachers' pedagogical content knowledge. Journal of Research in Science Teaching, 35(6), 673-695.

\section{Biographical note}

Betül Timur, Assist. Prof., completed her Ph.D. at Gazi University with a thesis on the development of pre-service science teachers' technological pedagogical content knowledge. She has been teaching science education courses including special topics in physics, science-technology-society, and science teaching since 2007. Her main research interests are inquiry based science, place and importance of science process skills, and technological pedagogical content knowledge.

Mehmet Fatih Tasar, Assoc. Prof., is a professor of science education. His main research interests are teaching and learning physics, cognitive foundations of learning, and history and philosophy of science. He was involved in the recent curriculum reform efforts in Turkey, which began in 2003 and continues today. He has published in international and national journals and has presented his scholarly works in many international and national meetings. Dr. Tasar is actively involved in science education research and serves as an academic advisor to several masters and doctoral students 